\title{
INDONESIA AND REGIONALISM IN SOUTHEAST ASIA, ASEAN AND INDONESIAN FOREIGN POLICY
}

https://doi.org/10.35344/japss.633421 Demet Sefika MANGIR ${ }^{1}$, Luthfy RAMIZ

\begin{abstract}
Research towards regionalism in Southeast Asia and Indonesian role within the regionalism process is concluded in this paper. Regional integration process in Southeast Asia within during the decolonization and ASEAN phases are assessed in this paper. Moreover, foreign policies and contribution of Indonesia towards the regional integration process is found important, considering its significant relative power among the other Southeast Asian nations. Research is conducted using the qualitative research method through the assessment of literatures, commentaries from the experts, and the agreements and protocols relevant to the research topics. The research concludes four important results; the dynamics of the regionalism in Southeast Asia, the theoretical construction of Southeast Asian Identity, theoretical assessments of regionalism in Southeast Asia and Indonesian foreign policy towards regionalism in Southeast Asia.
\end{abstract}

Keywords: Regionalism, ASEAN and Indonesia.

\section{ENDONEZYA VE GÜNEYDOĞU ASYA BÖLGESELCİLí̆̆̇̇, ASEAN VE ENDONEZYA DIŞ POLITIKIKASI}

ÖZ

Güneydoğu Asya'da bölgeselcilik ve bölgeselleşme sürecinde Endonezya'nın rolü konusundaki araştırmalar, çağdaş bölgeselci örgütlenmenin ortaya çıkmasından önce bile Güneydoğu Asya'daki entegrasyon sürecinin değerlendirilmesiyle sonuçlanmaktadır. Güneydoğu Asya'da dekolonizasyon ve ASEAN aşamalarında bölgesel entegrasyon süreci bu yazıda değerlendirilmiştir. Ayrıca, diğer Güneydoğu Asya ülkeleri arasındaki önemli göreceli gücü göz önüne alındığında, Endonezya'nın dış politikaları ve bölgesel entegrasyon sürecine katkısı önemli bulunmuştur. Araştırma, literatürlerin değerlendirilmesi, uzmanların yorumları ve araştırma konularıyla ilgili anlaşma ve protokollerin değerlendirilmesi yoluyla nitel araştırma yöntemi kullanılarak gerçekleştirilmektedir. Araştırma dört önemli sonuç çıkarmaktadır; Güneydoğu Asya'da bölgeselcilik dinamikleri, Güneydoğu Asya kimliğinin teorik yapısı, Güneydoğu Asya'da bölgeselliğin teorik değerlendirmeleri ve Güneydoğu Asya'da bölgeselleşmeye yönelik Endonezya dış politikasının teorik değerlendirmeleri.

Anahtar Kelimeler: Bölgeselcilik, ASEAN ve Endonezya.

\footnotetext{
${ }^{1}$ Dr. Öğr. Üyesi, Selçuk Üniversitesi İ̈BF Uluslararası İlişkiler Bölümü, demetacar@selcuk.edu.tr, ORCID ID: https://orcid.org/0000-0002-2542-8551

${ }^{2}$ Selçuk Üniversitesi İiBF Uluslararası İlişkiler Bölümü Doktora Adayı luthfyramiz.lr@ gmail.com, ORCID ID: https://orcid.org/0000-0002-0240-6431
} 


\section{Introduction}

Historical research towards the concept of regionalism has found that the world has witnessed the emergence of regionalism concept since the late of $19^{\text {th }}$ century. Some of the initial remarks of the emergence of regionalism in the international politics stage were the pan-Americanism and pan-Arabism. The emergence of the idea of regionalism during the pan-Americanism period had pushed through the ideas of sovereignty and freedom of the region from the colonialism (Fawcett, 2012, 8). Pan-Arabism was initially a consequence of the awakening of Arab identity and their history during the Ottoman Empire period (Danielson, 2007, 20). 20 ${ }^{\text {th }}$ century has marked the beginning of the contemporary regionalism study. The establishment of international institutions which led to the newly established parameters of regional and multilateral relationship and the post-colonialism period are the factors responsible to the significant development of regionalism concept in the $20^{\text {th }}$ century (Fawcett 2012, 8). While regionalism has arisen not only in America, Europe and Middle East, it has arisen as well in formerly long colonized regions, such as Southeast Asia. Regionalism in Southeast Asia had arisen after the most of the important actors in Southeast Asia were freed from colonialism and during the Cold War. Weber in his work has even mentioned that regionalism in Southeast Asia was initially rooted from the occurrence of Cold War (Weber, 2009, 4). Despite the regional organizations has existed prior to the formation of ASEAN, yet ASEAN is deemedto be the most contributive instruments for Southeast Asia in shaping regionalism in the area. Regional institutional constructions such as Bangkok Declaration 1967, Declaration of Zone of Peace, Freedom and Neutrality 1971 [hereafter, ZOPFAN Declaration], Treaty of Amity and Cooperation in Southeast Asia 1976, ASEAN Concord 1976, ASEAN Free Trade Area 1992 [hereafter, AFTA] and Charter of Association of Southeast Asian Nations 2007 [hereafter, ASEAN Charter], among others have shaped the essential framework of the regional integration in the region.

Aside from regional institutions, regional power's role in the formation of regionalism policy in a region is considerably important.First of all, regional powers' important role in the process of regional integration is visible in numbers of regionalism scheme, such as the roles of United States and Brazil in the formation of regional integration in the Americas and Germany in the European Union. Both United States and Brazil have had strong economic integration policy during the consolidation of the Free Trade Area of the Americas (Toru, 2004, 2-4) and Germany played significant role in the formation of European Economic and Monetary Union (Bulmer, 2015, 14-18). Indonesia's influence in regional political scene in Southeast Asia is considerably weighed. Indonesia is one of the founding states of ASEAN in 1967.Moreover physical wise, Indonesia tops the rank among other ASEAN members in regards of area and population. Security wise, Indonesia possesses the largest military power in the region (Normala, 2018). Meanwhile economic wise, Indonesia is ranked first in GDP among whole ASEAN members and has taken its position as the second most attractive location for transnational company in ASEAN and the second biggest in terms of foreign direct investment flow in the region, while the first one being Singapore in both category (Artner, 2018, 20). Should the term regional power is defined as having high influence in regional affairs (Neumann, 1992, 12), Indonesia is indeed a regional power in the region. In order to assess the regionalism in Southeast Asia and to assess the role of Indonesia as the regional power in shaping the regional integration in Southeast Asia, the research is based on four research matters. Firstly,research assesses the development of regionalism in Southeast Asia. Secondly, research assesses to conclude the Southeast Asian identities. Thirdly, research assesses the theoretical understanding of ASEAN Regionalist policy. Lastly, research assesses the theoretical understanding of Indonesia's policy towards regionalism in Southeast Asia.

\section{Theoretical Framework Of Regionalism}

To construct theoretical framework, research separately assess the emergence of regional integration to the regional integration mechanism. Moreover, in order to analyze the emergence 
of regionalism in Southeast Asia, author employs the constructivism, and realism theories. In order to analyze the occurrence of regionalism process, constructivism theory takes consideration of identity, social conventions and behaviors of states. Thus this theory is seen as the suitable approach as it emphasizes the motives of the formation of regionalism (Börzel, 2016, 43-44).

Constructivism Theory in international relations has emerged since the end of the Cold War. Generally, constructivist sees the importance of the states' identity and interests in constructing the system in which states' action takes place (Wendt, 1994, 385). Three significant elements in constructivism are norms, identity, and interest. The compatibility of identity of a state and its action is guided by norms. Thus norm holds important position on the eye of constructivists. Constructivists define norms as the standards in guiding the action of a state and its identity (Katzenstein, 1996, 5). Moreover, the corelation between norms, identity, policies, and international communities are elaborated as, internal and external norms shape identity of a state, which identity shapes normative structure of a state, and composition of identities shapes the international community (Japperson, et al., 1996; Katzenstein et. al., 1996, 52-53; Cho, 2009; 81).

Realism-Intergovernmentalism and Institutionalism approaches are also used in explaining the regionalism of Southeast Asia. Intergovernmentalism theory has its root from the realism school of thought. While realism school of thought can be traced back to its first emergence in the late 1500s through Hugo Grotius.Realism theory comprises three important feature; anarchy, state, and rational decision making (Antunes \& Camisao, 2017; 15). Anarchism represents the absence of supreme role in international politics. Moreover, state represents its sole power as the actor of international politics. Through the necessity to achieve their interest, state carries out action. States have necessity for security in response to the anarchic structure and to the unbalanced power (Williams, et. Al, 2006; Chen 2011, 27-28). Thirdly, rational decision making is carried out by the state to minimize harm to the interest. Research towards the role of Indonesia as regional power in shaping regional integration in Southeast Asia can be based on the realists' view in the formation of international cooperation. Realists see the importance of the existence of a bigger power in order to establish international cooperation with stable norms, rules and procedures (Cho, 2009; 78). In connecting the state and its interests, the norms, rules and procedures are the products of the adjustment to the hegemonic state's interests.

Neo-realism eventually conceived a more elaborative explanation of power balance in the integration process. The proper combination of international politics is the existence of balance of two big powers (Bell \& Duignan, 2017). Moreover, the facts that states have capability in security aspect, big power could be a threat to security at any time and anarchism has given states no guarantee of security have pushed the states seek power in order to protect. This led to a formation of cooperation, which is deemed as the solution (Ngan, 2016, 2-3).

Intergovernmentalism is a sub-theory of realism theory that author uses in analyzing the regionalism in Southeast Asia. Prominent feature of intergovernmentalism is that it sees regionalism as the integration and bargaining process between national governments in particular region (Moravcsik, 1991, Yoshimatsu, 2008, 63). Intergovernmentalism sees integration process as the feature where governments of the member state are authorized to determine the processes of the integration; such as the substance and speed of integration (Schimmelfenning \& Rittberger, 2006, 77-78).

Process of bargaining towards integration in intergovernmentalism theory is based on the state preferences. State preferences are seen distinct between liberal intergovernmentalism and realist intergovernmentalism. Liberal intergovernmentalism, or neofunctionalism, sees the state preference to be sector-specific (Schimmelfenning \& Rittberger, 2006, 77-78). In this case, the preferences are mostly in economic sector and domestic preference based on internal demands (Coşkun, 2015, 388). On the other hand, realist intergovernmentalism sees the state preference 
to be based on the concern of their own autonomy and influence (Schimmelfenning \& Rittberger, 2006, 78).

The element of supranationalism, that mostly presents in neofunctionalism theory, is absent in this theory (Rosamond, 2000, 141). Contrary to the importance of institution in upholding integration process in supranationalist perspective,the role of institution in the regional integration process according to intergovernmentalism theory is to bind the member states through international agreements (Sweet \& Sandholtz, 1997, 301). Moreover, the role supranational institution is limited in supervising the regional interaction and the daily affairs of the region (Yang, 2014, 7).

Intergovernmentalism emphasizes the relative power of states and power of largest states in the region (Yoshimatsu, 2008, 64).Each state in any particular regions has different relative power. States with smaller power might possess less influential position whilst bigger powers possess more influential position.Emphasis of power exists in this theory is correlated to the bargaining process as the key variable to this theory. Interaction between member states depends on the relative power of states and states with biggest power might have the most significant influence to the outcome of the bargaining among other states (Eliassen \& Arnadottir, 2016, Telo, 2014, 243).

Institutionalism theory is rather extensive, as it has evolved to neo-institutionalism and neoliberalist institutionalism. Instutionalism features five prominent characters; these characters are legalist, structuralist, holicist, historicist, and normative (Peter, 1999, 7-11). The view on institutionalism as legalist is attributable to centrality of law in the carrying out the governing function (Peter, 1999, 7). Then, the theory is considered structuralist as it is formal, or is based on constitutional arrangement (Peter, 1999, 8). Consideration of holism of institutional theory is attributable to its holistic analysis of the systems, and it refrains from analyzing particular system partially (Peter, 1999, 9). Moreover, historicist character of this theory is visible through the history-based analysis that most of institutionalists carry out. Institutionalists see how the contemporary system is presence in the history, and in the status quo of political, socioeconomic and cultural aspects (Peter, 1999, 10). Finally, institutionalism theory's emphasis on the norms and values has shown the source of the normative side of institutionalism theory (Peter, 1999, 11).

Evolvement of institutionalist perspective is known to be neo-institutionalism. Institution plays significant role in conceiving order, and the robust foundation to the individuals and surroundings (Olsen, 2007, 3). Institution is central in providing the ideational norms and resources to individuals (Bell, 2002, 3). Furthermore, foundation of a robust regional community is a strong institution, as institution plays its role as the game's ruler and it connects the members of the community and their action (Rattanasevee, 2014, 1). Rule is followed for its proper "guide" and "validity" (Bell, 2002, 3).

When it comes to evaluation of the establishment of institution, author employs the neoliberal approach of neo-institutionalism theory. Neoliberal institutionalism sees institution is established to accommodate states' interdependence and interaction towards each other in acting for its interest and achieving maximal utility (Jonsson \& Tallberg, 2001, 5). This is supported by the view that sees the formation of institution is a way-out in solving the coordination, collaboration and governance cost problems of states (Stein, 2008, 208-209).

\section{Southeast Asia Treaty Organization, Association of Southeast Asia And Maphilindo}

SEATO, ASA and MAPHILINDO were three important elements that constructed regional integration process in Southeast Asia before the culmination of ASEAN. For Southeast Asia, Cold War and regionalism is sort of causal effect relations. United States has first cultivated its influence in the region through the colonization of the Philippines. Nevertheless, Soviet Union 
was planning to expand their influence to Southeast Asia, which they deemed as "colonial areas" (Leffler, 2006, 2). The establishment of Southeast Asia Treaty Organization [hereafter, SEATO] was the direct effect of this ideological war, as it waspart of United States' Containment Policy, which was a policy conception made to counter the growth of Communism and the expansion of Soviet Union in Southeast Asia.

The provision of the use of force against communist aggression in Southeast Asia was visible in Article IV Paragraph (1) of SEATO Treaty $1954^{3}$. The provision in this article stated that in the event aggression occurred in the territory of any member state and Laos, Cambodia and South Vietnam according to the treaty, the member states agreed to take action. In response to this mechanism, Indonesia and Burma opposed the idea of SEATO establishment.As for Indonesia, itmainly criticized the intervention of non Southeast Asian nations in maintaining the security in the region (Pilliter, 1969, 85-86).

The contemporary regionalism in Southeast Asia is rooted from the establishment of regional cooperation of Association of Southeast Asia [hereafter,ASA]. ASA was established in 1961 after the signatory of the Charter of Association of Southeast Asia was signed on 31 July 1961 by Federation of Malaya, the Philippines and Thailand.ASA was characterizedby its loose structural bodies. Despite of this, it still maintained the simple structural organization. Annual Meeting of Foreign Affairs Minister was the most important governing structure; Standing Committee substituted the task of Annual Meeting to consult on policy; the other bodies are National Secretariats and the Permanent Committees on socio-cultural field, economic field and technical cooperation and research field (Fifield, 1979, 4). Cooperation within the framework of ASA focused in economic and socio-cultural functions. Manifestation of ASA's economic and socio-cultural functions was visible in the agreement dealt within its period of existence. Malaya and Thailand agreed to contribute to ASA through grant of 1 million Malayan Dollar. Moreover, the Philippines agreed to assist Malayan health program through dispatching sixty medical doctors (Ness, 2015, 1-4). Moreover, ASA agreed to conclude multilateral agreements on trade and navigation between member states, to abolish visa requirements for officials and to initiate visa fee waiver program for ASA nationals, to consider the establishment of special reduced rates for press and telegram among member states and to inaugurate railway services between Kuala Lumpur and Bangkok (Ness, 2015).

Afterward the establishment of ASA, MAPHILINDO was established by Malaya, the Philippines and Indonesia and was the initiatedby the president of The Philippines, Diosdado Macapagal. The establishment of MAPHILINDO was preceded by the foreign affairs ministerial meeting took place between 7 to11 June 1963 in Manila. Eventually, the signatory of Manila Accord 1963 and Manila Declaration 1963 by the three states taken place during the summit remarks the birth of MAPHILINDO.Constructivist perspective on the establishment of MAPHILINDO is visible through its shared identity background of its member states. MAPHILINDOwas historically established after the vision of the Philippines' Jose Rizal to unite the colonized nations of Malay Heritage (Fry, 2008, 43) and the similar vision of the union of Malay people, which was coined as "Malay Irredenta", envisaged by a Philippine politician, Wenceslao Vinzons (Reid, 2010,100).

Sovereignty and informality principles constructed the very idea of MAPHILINDO. The Philippines, Indonesia and Malaya have consensually agreed to a conception of 'a group consists of three nations of Malay origin working together in harmony, with no disruption to each of the nation's sovereignty' (Stockwell, 2004, 650). The emphasis on sovereignty and informality principles, which the latter was defined through the implementation of consultation

\footnotetext{
${ }^{3}$ Article IV, Paragraph (1) of Southeast Asia Collective Defence Treaty 1954: “(1) Each party recognizes that aggression by means of armed attack in the treaty area against any of the parties or against any state or territory which the parties by unanimous agreement may hereafter designate, would endanger its own peace and safety, and agrees that it will in that event act to meet the common danger in accordance with its constitutional processes..."
} 
mechanism, of MAPHILINDO is visible in the position taken by the organization in the case of North Borneo dispute between the Philippines and Malaya. Paragraph (4) of the Joint Statement of the Heads of Government 1963 [hereafter, Joint Declaration 1963] ${ }^{4}$ and Paragraph (11) of Manila Accord $1963^{5}$ states that the settlement of the dispute should consider the determination of the people of North Borneo through the evaluation of the referendum that was conducted in the area and this would be the basis for the consultation arranged to settle the dispute.

\section{ASEAN And Contemporary Regionalism In Southeast Asia}

Signatory of Bangkok Declaration 1967 by half of independent states in Southeast Asia; Indonesia, Malaysia, Singapore, Thailand and the Philippines (ASEAN-5) has remarked the establishment of ASEAN. ASEAN was established in the year 1967. Moreover, corresponding with the values in Bangkok Declaration 1967, three essential grounds of ASEAN are the reduction of tensions and competitions among the member states, promotion of domestic socioeconomic development, and reduction of influence of external actors in regional military power (Narine, 2002, 13). ASEAN membership expansion took place between 1975 and 1999. Following the end of Vietnam War in 1975, Brunei joined as the new member 1984. Moreover, following the end of Cold War in 1991, four more states joined the organization. Vietnam joined in the year 1995, Laos and Myanmar joined in 1997 and eventually Cambodia joined ASEAN in 1999. Organizational structure wise, ASEAN has developed from its early establishment to its current situation. Paragraph (3) of Bangkok Declaration $1967^{6}$ states that machinery of ASEAN is comprised of Annual Meeting of Foreign Ministers, Standing Committee, Ad-Hoc Committees and Permanent Committees, and National Secretariats. On the other hand, the current working organs of ASEAN comprise of nine working bodies and are set in ASEAN Charter $2007^{7}$. While the supreme body of ASEAN is the ASEAN Summit, the other bodies that hold significant role in the course of the organization; namely ASEAN Coordinating Council, ASEAN Community Councils, ASEAN Sectorial Ministerial Bodies, SecretaryGeneral and ASEAN Secretariat, Committee of Permanent Representatives, ASEAN National Secretariat, ASEAN Human Rights Body and ASEAN Foundation.

ASEAN Summit holds the supreme position among the working body of ASEAN at whole. The summit comprises the head of state or head of government of the member states. Meanwhile, the Secretary-General and four Deputy Secretaries-General carry out the high-office responsibility. Secretary-General is responsible for policy and decision making process, facilitating and monitoring the implementation of ASEAN agreements and decision, participating at the meetings of the ASEAN organs and other external organs that are approved by the policy guidelines.

\footnotetext{
${ }^{4}$ Paragraph (4) of Joint Statement 1963: “...the opinion of the Secretary-General is necessary to ensure complete compliance with the principle of self-determination within the requirements embodied in Principle 9, taking into consideration : (i) the recent elections in Sabah (North Borneo) and Sarawak but nevertheless further examining, verifying and satisfying himself as to whether (a) Malaysia was a major issue, if not the main issue ; (b) Electoral registers were properly compiled; (c) elections were free and there was no coercion; and $(d)$ votes were properly polled and properly counted ;...".

${ }^{5}$ Paragraph (11) of Manila Accord 1963: "The Federation of Malaya expressed appreciation for this attitude of Indonesia and the Philippines and undertook to consult the British Govern ment and the Government of the Borneo territories with a view to inviting the Secretary-General of the United Nations or his representative to take the necessary steps in order to ascertain the wishes of the people of those territories.".

${ }^{6}$ Paragraph (3) of Bangkok Declaration 1967: "to carry out these aims and purposes, the following machinery shall be established: (a) Annual Meeting of Foreign Ministers, which shall be by rotation and referred to as ASEAN Ministerial Meeting. Special Meetings of Foreign Ministers may be convened as required. (b) A Standing committee, ... (c) Ad-Hoc Committees and Permanent Committees of specialists and officials on specific subjects. (d) A National Secretariat in each member state to carry out the work of the Association on behalf of that state and to service the Annual or Special Meetings of Foreign Ministers, the Standing Committee and such other committees as may hereafter be established."

${ }^{7}$ ASEAN Charter 2007 is available at https://asean.org/storage/2012/05/The-ASEAN-Charter-26th-Reprint.pdf (accessed on 30 March 2019).
} 
Southeast Asian approach to regionalism is based on the set code of conduct, namelythe "ASEAN Way". These codes of conduct are, 1) adherence to non-interference, non-use of force, and peaceful resolution of conflict, 2) promotion of national resilience and regional resilience 3) rejection of multilateral military pact and acceptance of bilateral defence cooperation pursued by individual member states, 4) preference for consultation and consensus mechanism (Heng, 2014, 2).

Regional integration in Southeast Asia, through the establishment of ASEAN and the conception of "ASEAN Way", is fashioned to preserve sovereignty of each state in the region (Vatikiotis, 1999, 17). The norms are rooted from the fact that Southeast Asia comprises states of different ideologies and the region had gone through the struggles in the past. Therefore in order to protect each member state's sovereignty and to achieve the stability when carrying out regional integration efforts, non-interference principle has been the basic value. On the top of that non-interference principle is seen as the center of ASEAN conduct (Jones, 2009,3).

Owing to its status as the shared value of Southeast Asian states, consultation was deemed to be originated from traditional Malay culture (Kim \& Lee, 2011, 953-957). Furthermore, consultations have contributed significantly to the formation of cultural norms in the region (Acharya \& Layug, 2015, 8-11). This is proven by the use of consultation mechanism by MAPHILINDO for achieving consensus in conducting the cooperation during its era.

Regional cooperation frameworks formed by ASEAN are ranging from different field of sectors. ASEAN has formed cooperation in the fields of politics, security, economics, and culture. Southeast Asia's contemporary regionalism in political-security sectors is marked through the emergence of regional policies and the establishment of regional organs and dialogue partnership to cover numerous regional stability matters. In addressing politicalsecurity cooperation more extensively, Article (1) Paragraph (2) of the ASEAN Charter states that the purpose of ASEAN extends to promoting extensive cooperation in political-security sectors $^{8}$.

The matters covered in the political-security cooperation are comprised of disarmament and non-proliferation of nuclear weapon, transnational crime and terrorism, South China Sea partnership, Human Rights protection, and peaceful settlement of dispute, and extradition mechanism.

Implementation of non-interference norm and cooperation in political-security sectors during the early period of ASEAN establishment is visible in the adoption of ZOPFAN Declaration. ZOPFAN declaration expressed two emphases regarding the political-security sector in Southeast Asia. Firstly, it re-emphasized that Southeast Asia as a region that is free from any interference from foreign interference. Secondly, ZOPFAN Declaration assigned the Southeast Asian countries to carry out effort to widen the area of partnership. Therefore it could develop their strength, solidarity and relations.

Southeast Asia's contemporary regional integration in socio-economic sectors is marked through the emergence of ASEAN Economic Community [hereafter, AEC] framework. Main emphases of AEC are the economic development through single market, production base, economic competitiveness, equal economic development and integration into global economy. In order to implement those emphases, AEC aims to establish mechanisms to implement the economic initiatives, regional integration in priority sectors, free movement of goods, people, and investment, and to implement institutional mechanism.

The free trade area symbolizes the single market and production base initiative of ASEAN. History of free trade area in Southeast Asia started off in 1970s when the regional economy was somehow limited to sectoral economic cooperation (Intal, Jr., 2017, 269). The adoption of

\footnotetext{
${ }^{8}$ Article (1) Paragraph (2) of ASEAN Charter: “The Purposes of ASEAN are...(2) To enhance regional resilience by promoting greater political, security, economic and socio-cultural cooperation...".
} 
ASEAN Preferential Trading Arrangements Agreement 1977 was deemed to be the initial step of trade agreement under ASEAN framework.

ASEAN PTA Agreement 1977 was eventually succeeded by the initiation of the AFTA through the signatory of Agreement on Common Effective Preferential Tariff (CEPT) Scheme for ASEAN Free Trade Area 1992 [hereafter CEPT-AFTA Agreement] ${ }^{9}$. CEPT-AFTA is an important instrument in covering key matters of the trade, tariff reduction mechanism, investment and some other matters. Apart from symbolizing the initiative of single market and production base, CEPT-AFTA symbolizes economic integration in Southeast Asia (Balassa, 1961, 1-17). Moreover, CEPT-AFTA mechanism aims to increase the foreign direct investment (Liew, et. al., 2017, 641).

PTA and AFTA have given different impact during its implementation. ASEAN PTA 1977 gave underwhelming impact (Mansor \& Radam, 2000). On the other hand, AFTA has shown increase in trade quantity between members. From 2015 to 2016, the trade has grown up to 25,9\% (Alber, 2017).

The signatory of ASEAN Framework Agreement on Services [herafter, AFAS] 1995, Basic Agreement on the ASEAN Industrial Cooperation Scheme [hereafter, AICO Agreement] 1996, and ASEAN Comprehensive Investment Agreement [hereafter, ACIA Agreement] 2009 have marked the initial effort of ASEAN in regionalizing the service trade, industrial cooperation and investment.

The expansion of AFTA mechanism has resulted on the foreign direct investment inflows. Overall foreign direct investment inflows from 1995 to 2017 in Southeast Asia increased up to 12\% (ASEAN, 2018, xv11.). Singapore, Indonesia and Vietnam were the three largest countries in ASEAN in foreign direct investment rate.

Other policy that supports the regionalism process is the free movement of people. ASEAN member countries have signed The Mutual Recognition Arrangements and ASEAN Agreement on Movement of Natural Person. Freedom movement policy within ASEAN region is limited to member countries' responsibility to facilitate movement of particular type of persons (Koh, 2017).

Cooperation in social sector is comprised the issues of improving human development, and social justice and welfare,environmental protection, building ASEAN identity and achieving narrower development gap.ASEAN has adopted Declaration on the Protection and Promotion of the Rights of Migrant Workers 2007 and Declaration on the Elimination of Violence against Women and Children 2013 and ASEAN's diplomatic-humanitarian approach to Myanmar crisis. While in environmental sector, ASEAN has signed the Agreement on Transboundary Haze Pollution 2002, Agreement on Disaster Management and Emergency Response 2005, and establish ASEAN Coordinating Center for Humanitarian Assistance to establish mechanism in handling annual haze pollution in particular forest fire spots in Southeast Asia and in handling assistance in response to disasters, which Southeast Asia is vulnerable to.

The prominent, yet disguised, diplomatic-humanitarian approach of ASEAN in coping with the humanitarian crisis took place after Cyclone Nargis hit Myanmar is one of the implementation of the regional cooperation in social sector. The cyclone Nargis hit Myanmar on May 2008 and death toll reached 138.000. Nevertheless, Myanmar Government refused the foreign aid. Instead through the application of sanction and condemnation, ASEAN brought this humanitarian issue to negotiations, and encourage Myanmar to settle the problem internally (Vejjajiva, 2017, 352).

\footnotetext{
${ }^{9}$ Agreement on Common Effective Preferential Tariff (CEPT) Scheme for ASEAN Free Trade Area 1992 is available at https://asean.org/?static_post=agreement-on-the-common-effective-preferential-tariff-cept-scheme-for-the-aseanfree-trade-area-afta (accessed on 12 July 2018).
} 
Cooperation between ASEAN and these external parties are established in the forms of inter regional dialogue, free trade area, bilateral dialogue, sectoral dialogue partnerships and development partnership. The most prominent inter regional dialogue frameworks established by ASEAN include ASEAN Regional Forum ${ }^{10}$ [hereafter, ARF], ASEAN $+3^{11}$ and East Asia Summit ${ }^{12}$. Despite Inter regional dialogue mostly focuses to build cooperation in the field of political-security sector, some of the dialogue framework is multifaceted as it also touches economic cooperation sector, such as ASEAN+3 (US Dept. of State, 1994; Tulun, 2018). ASEAN widens its economic integration policy through the establishment of free trade area with external states. Inter regional free trade areas established by ASEAN includes the free trade areas with China, Korea, Japan, Australia, New Zealand, and India.

Article (44) Paragraph (1) of ASEAN Charter gives legal certainty to the Dialogue Partner, Sectoral Dialogue Partner, and Development Partner as integral parts of ASEAN external relations. The dialogue partners of ASEAN include Australia, Canada, China, European Union, India, Japan, New Zealand, Russia, South Korea, United States and UNDP. Meanwhile, some countries have shown the interest of becoming ASEAN's Dialogue Partner. These countries include Sri Lanka, Mongolia, Kazakhstan, Brazil and Mexico (Haacke \& Breen, 2018). The dialogue partnership covers particular sectors, such as politics and economic partnership. Coverage on more specific issues which the partnership between ASEAN and dialogue partners include promotion of ASEAN economics, trade and economic concessions, political cooperation, and assistance in technical and developmental field (Hamzah, 1989; Ulfiana, 2014, 3). Moreover, the mechanism of dialogue partnership of ASEAN is carried out through consultation mechanism done at the minister meetings of the parties involved, such as ASEAN Defense Minister Meeting Plus [hereafter, ADMM-Plus] and ASEAN Economic Minister Plus Three. ASEAN sectoral dialogue partnership and development partnership are other frameworks of ASEAN inter-regional network apart from the aforementioned mechanisms. Five countries that fall on these partnership categories are Pakistan, Norway, Switzerland, Germany and Turkey.

\section{Foreign Policy And Regionalist Policy Of Indonesia}

Regionalist policy of Indonesia can be traced back to the pre colonial period of Indonesia. Precolonial foreign policy history of Indonesia was rather complex. The existence of informality (Wolters, 1999, 30), trade diplomacy of Samudera Pasai Sultanate and Srivijaya Kingdom (Abdullah, 1989, 20-21, Dellios \& Ferguson, 2017, 104), and the intra interstatealliance established by Majapahit and Srivijaya kingdoms (Ooi, 2004, 823,Heng, 2009, 84). Its independence in 1945 has been the turning point for foreign policy of Indonesia. Afterward the independent proclamation, foreign policy of Indonesia has always been rooted from Pancasila ${ }^{13}$ as its national ideology, 1945 Constitution, and the 'Bebas-Aktif' policy (Hellendorff \& Schmitz, 2014, 3). Pancasila serves as the basis for Indonesia to act in order to achieve its own interests in international politics, meanwhile 1945 Constitution elaborates three main interests of Indonesia in carrying out its foreign policy (Putera, 2018). The main interests as Indonesia's

\footnotetext{
${ }^{10}$ ASEAN Regional Forum members include: Bangladesh, Brunei Darussalam, Cambodia, Canada, China, European Union, India, Indonesia, Japan, Laos, Malaysia, Mongolia, Myanmar, New Zealand, North Korea, Pakistan, Papua New Guinea, The Philippines, Russia, Singapore, South Korea, Sri Lanka, Thailand, Timor-Leste, The United States of America, and Vietnam.

${ }^{11}$ ASEAN+3 members include: Brunei Darussalam, Cambodia, China, Indonesia, Japan, Laos, Malaysia, Myanmar, The Philippines, Singapore, South Korea, Thailand, and Vietnam.

12 East Asia Summit members include: Brunei Darussalam, Cambodia, China, India, Indonesia, Japan, Laos, Malaysia, Myanmar, New Zealand, The Philippines, Russia, Singapore, South Korea, Thailand, The United States of America, and Vietnam.

${ }^{13}$ Pancasila is properly transliterated as "Five Moral Principles"; 1) Belief in one and only God, 2) Just and civilised humanity, 3) The unity of Indonesia, 4) Democracy guided by the inner wisdom in the unanimity arising out of deliberations amongst representatives, 5) Social justice for all of the people of Indonesia.
} 
focuses in its foreign policy are, 1) to protect Indonesian nationals, 2) to achieve public welfare, 3 ) to educate the nation, and 4) to participate in implementing the world order based on the independence, peace and social welfare.

The 'Bebas-Aktif' Policy is properly transliterated to "Independent-Active". The policy contains two main principles of the foreign policy that Indonesia pursues. The term "independent" is understood as Indonesia'simpartiality in carrying out its role in international politics, in the sense that Indonesia does not take side either to the Communist Bloc or to the Western Bloc (Haryanto, 2014, 23). Moreover, "active" is understood as Indonesia's vision to active contribution to achieve peace and to muffle the tension created by the ideological competition between the two blocs by carrying out every way possible according to the common values of the United Nations (Hatta, 1953, 444).

Eventually the 'Bebas-Aktif' Policy was abandoned whilst Soekarno directed Indonesia's foreign policy to a new extreme through the "Guided Democracy" concept. Firstly, the "New Emerging Forces" [hereafter, NEFOS] was established to counter the "Old Established Forces" [hereafter, OLDEFOS] which was comprised of neoimperialist -and capitalist- states led by the United States (Dayley, 2018, 240). Secondly, Soekarno had maintained even closer relation with China, which it resulted to the lift of economic aid from the United States and eventually led to the economic collapse (Gregorian, 1991, Beckett, 2007, 60). Thirdly, confrontation policy emerged as a reaction towards the formation of Malaysian Federation on 16 September 1963.

It is believed that the negative attitude towards the amalgamation of North Borneo to the Malaysian Federation by the United Kingdom was the root of the confrontation policy. Furthermore, there were two factors which had pushed Soekarno to carry out Confrontation Policy. The first one was the sympathy given by Soekarno to the rebellion of North Borneo people, while the second one was the concern from Soekarno towards the claim of The Philippines on the Sabah part of North Borneo (Pujiastuti, et. al., 2007, 86), as United Kingdom unified North Borneo to the Malaysian Federation. The confrontation policy ended in 1965 in conjunction with the fall of the "Guided Democracy" and Soekarno's regime, and the rise of The New Order in Indonesia with Soeharto, who was an anti-communist leader, took the lead. The main focus of the "New Order" Regime was mainly carrying out the "damage control on the foreign policy" from the previous regime. The initial mark of Indonesian Foreign Policy under the "New Order" Regime was the reinstatement of the "Bebas-Aktif" Foreign Policy (Leifer, 1973, 173). The "Bebas-Aktif" Policy was reinstated through the provision of The Provisional People's Consultative Assembly Number 12/1996 ${ }^{14}$.

Apart from the reinstatement of the "Bebas-Aktif" Policy, Indonesia has also moved to normalize its relations with Malaysia (Pujiastuti, et. al., 2007, 86). Another milestone for the "New Order" Regime was the establishment of ASEAN in 1967. The establishment of ASEAN was carried out by Indonesia, Malaysia, Thailand, The Philippines, and Singapore. Moreover, it is noted that Indonesia was the state which endorsed the sovereignty, non-interference, and national resilience principles as the norms of ASEAN (Situmorang, 2017, 64).

Foreign policy of Indonesia under the "New Order" Regime was noted as political-economic oriented, regionalist and at the same time globalist. "New Order" Regime's political steps of normalization its diplomatic relations with Kuala Lumpur, consideration of regional political turbulence, such as self-determination of North Borneo people, as matter (Pujiastuti, et. al., 2007, 87), and most importantly restoration of Indonesia's "Bebas-Aktif' Policy have shown the regime's political-oriented character in foreign policy matter. Meanwhile the regime's foreign policy is deemed as economic oriented for its effort to achieve maximum utilization of international sources to restructure the nation's collapsed economy (Yani, 2009, 9), trade

\footnotetext{
${ }^{14}$ Provision Number XII/MPRS/1966 is available at http://www.tatanusa.co.id/tapmpr/66TAPMPRXII.pdf [Indonesian] (accessed on 15 April 2019).
} 
liberalization through the membership at Asia-Pacific Economic Cooperation [hereafter, APEC] (Ravenhill, 2001, 105-107). Regionalist, as the regime had put its focus in the building regional intergration, such as ASEAN; and furthermore arranging regional resilience concept. Finally, foreign policy under the "New Order" Regime is deemed globalist for its active role in NonAligned Movement [hereafter, NAM], and United Nations through its achievement as the nonpermanent member of The Security Council in 1995-1996 (Yani, 2009, 8).

Foreign policies of Indonesia under the post-New Order regimes have shown rather similar characteristics. Cited from Yani in his work, with the exception to the Abdurrahman "Gus Dur" Wahid Regime from 1999 to 2001, most of foreign policies between 1999 and the 2000s were noted for its regionalist approach, with focuses on political-economic stability and its implementation ranging from regional autonomy, free trade and private investment (Yani, 2009, 6). Joko Widodo, however, has shown realist, regionalist and maritime approach in foreign policy under his leadership (Shekhar, 2018,15-17). Realist as it is seen to be directing its foreign policy on political-economic interests by employing realist approach (Shekhar, 2018, 15-17), regionalist and maritime-oriented as the regime tend to put its focus on shaping its Indo-Pacific regionalist concept.

Indo-Pacific regionalist concept is implemented through the creation of "Poros Maritim Dunia" conception, or "Global Maritime Axis". The essence of the conception is the aspiration for Indonesia in becoming a strong, stable, and prosperous maritime nation therefore it can play bigger role through utilizing its strategic position between Indian Ocean and Pacific Ocean (Manurung, 2018, 148).

\section{Identities of Southeast Asia}

The composition of identities is assessed through four important measurements proposed by Rawi, et. al. which are "constitutive norms", "social purposes", "relational comparisons", and "cognitive models" (Rawi, 2006, 711, Acharya \& Layug, 2015, 5-6). Constitutive norms are visible in the preamble of ASEAN Charter and Bangkok Declaration, which these include sovereignty, non-interference, informality through consensus, and cooperation. As for social purposes $^{15}$, the objectives stated within the ASEAN Charter and the Bangkok Declaration 1967 can properly cover the this measurement. These include the objective of achieving national resilience (such as, reduction of development gap and stability), and regional resilience (such as, economic, social and cultural cooperation, stability, nuclear weapon free zone, sustainable development and secure environment, and agriculture and industries collaboration). As for relational comparisons measurement ${ }^{16}$, the identity of security cooperation is more appropriate to ASEAN instead of security alliance. ASEAN has never declared itself as a security alliance, unlike SEATO. This refers to non-interference norms recognized by ASEAN normatively. Moreover, this argument seems compatible to Acharya and Layug's view on ASEAN as a security community (Acharya \& Layug, 2015, 6). Finally, cognitive model measurement ${ }^{17}$ measures Southeast Asia as one decolonized region, which was deemed as one battlefield of ideological interests during the Cold War period.

\section{Theoretical Understanding of ASEAN Regionalist Policy}

The structural aspect of ASEAN Regionalism can be assessed by using intergovernmentalistapproach. At this point, intergovernmentalists see four important measurements in elaborating integration process. These measurements are the bargaining

\footnotetext{
15 "Social Purposes" are defined as shared objectives among the member of actors(Acharya \& Layug, 2015).

16“Relational Comparisons" are defined as the comparison to other identity groups (Acharya \& Layug, 2015).

17“"Cognitive Model” is defined as understanding of a political condition and interest shaped by particular identity (Acharya \& Layug, 2015).
} 
process, state preferences, institutional influence, and relative power.Bargaining process in ASEAN is carried out through the informal mechanism, especially the consultation mechanism. The consultation mechanism is mentioned within the Article (2) Paragraph (2) Letter (g) of the ASEAN Charter. In regard of the state preferences, there is compatibility of ASEAN Regionalism to the view of the realist intergovernmentalists' perspective. The compatibility is visible in the fact that ASEAN provides less binding integrational mechanism, compared to those of European Union, where ASEAN member states holds wider autonomy in regional integration process thanks the sovereignty principle and informality characters within the bargaining process.

Inexistence of complex legislative constitutional procedure and bodies in ASEAN has shown the role of institution in ASEAN as to be limited to bind the member states and to supervise the run of the organization. ASEAN, unlike EU which has complex decision making procedure and bodies (Schonard, 2018), employs ASEAN Summit as the single body to conduct decision making process. Intergovernmentalist approach sees relative power as one of element which defines regionalism. At this point, Indonesia holds the biggest power among ASEAN member states with the biggest area, population and one of the biggest economic powers among Southeast Asian countries. The influence of bigger power in ASEAN Regionalism is somehow proven by some examples that were given earlier in the case of the consensus on Indonesia's proposal in enshrining the sovereignty, non-interference and national resilience principles to ASEAN (Situmorang, 2017, 64). As for realists' and neoliberal institutionalists' perspective on the smaller powers, the existence of ASEAN as institution enables the support for them in both achieving power balance to minimize the anarchic threats and maximizing the utilization to reach their own interest.Neoliberal institutionalism and realism theories are also used in assessing ASEAN's interregional cooperation. Roloff's combination of realism and neoliberal institutionalism theories, which sees cooperation as symbol of effort made by states to deal with global interdependence and to achieve the balance in order to face the incoming challenges from other regions (Masala \& Roloff, 1998, 61-94), as compatible in describing the realness of interregional cooperation of ASEAN. For example, interdependence of ASEAN towards its interregional partners in trade is inevitable. The biggest numbers of ASEAN trade belongs to China, Japan and European Union counted up to $15.2 \%, 10.5 \%$ and $10 \%$ respectively. While the overall number of interregional trade with interregional partners reaches up to $56.9 \%$ of overall ASEAN trade (ASEAN, 2016).

Interdependence of ASEAN to interregional partners in investment sector is visible through the FDI Inflows to ASEAN. As per2015, European Union, Japan, and United States share the top three highest investment flows share to ASEAN counted up to $16.7 \%, 14.5 \%$, and $11.3 \%$ respectively (ASEAN, 2016). Meanwhile, the biggest FDI Inflows increase between 2013-2014 and 2014-2015 came from New Zealand, India and Russia counted up to 307,5\%, 161,4\% and $74,5 \%$ respectively (ASEAN, 2016). ASEAN partnership with big powers, such as China and United States could provide an example of power balancing effort. China and United States are both "hegemony" powers in Southeast Asia. United States was deemed to be the sole power in across East Asia until China keeps up with its effort to narrow the gap when it comes to military power in the region (Layne, 2018, 95). Cliff in his work has even predicted that China's overtake of US military hegemony across East Asia by the year 2020 (Cliff, 2015,244-246, Layne, 2018, 95). Moreover, some scholarly works have assessed the power balance of effort of ASEAN towards some other powers. Such as China and India power balance in economic and political-security manners (Tripathi, 2015, 69-70).

\section{Theoretical Understanding of Indonesia's Policy towards Regionalism in Southeast Asia}

Constructivist and Realist approaches are used to assess Indonesia's policy towards regionalism in Southeast Asia. The former is used to assess ideology of Indonesia and its position in regional integration in the region, while the latter is used to assess foreign policy emphases of Indonesia. 
Indonesia has applied the 'Bebas-Aktif' Policy and "Guided Democracy" conception during much of its existence. Impartiality character from the 'Bebas-Aktif' Policy has contributed much to the skeptical attitude of Indonesia towards the regionalism process during the SEATO period. Furthermore, the emergence of the "Guided Democracy" Conception has shifted Indonesia to a leftist tendency in applying its foreign policy. This is proven by the existence of NEFOS and it has driven Indonesia farther from the regionalism process in Southeast Asia, which mostly driven by the Western bloc-or infested with Western affiliated member states. The emergence of the "New Order" regime was the new beginning for Indonesia. Soeharto, who was the leader during the "New Order" Regime, envisaged in building regional cooperation with other anticommunist states, or the ASEAN-5. Therefore the anti-communist ideology is the shared identity among the founding states of ASEAN in 1967.

There exists the constructivist element in the enshrinement of sovereignty and non-interference norms as the constitutive norms of ASEAN through the contribution of Indonesia. As it has been elaborated earlier in this research, Indonesia maintains its national value of independence, peace and social welfare in achieving its objective to implement the world order. In assessing the constructivist element, one should refer to the idea which states that internal and external norms shape identity of a state and composition of identities shapes the international community (Jepperson, et al., 1996; Katzenstein et. al., 1996, 52-53, Cho, 2009; 81). Clearly, the case of Indonesia as the endorser of the sovereignty and non-interference values to ASEAN has reflected the formation process of constitutive norms of ASEAN and Indonesia's contribution to the process. Realist approach describes the natural character of Indonesia as the "bigger power" in sustaining regional integration process in Southeast Asia, especially during the "New Order" Regime. Indonesian foreign policy in the "New Order" Regime was envisaged in building regional integration process in Southeast Asia, whilst at the same time the foreign policy of Indonesia during the "New Order" Regime was also deemed to aspire in maximizing the utilization of the international source in order to restructuring Indonesia's collapsed economy (Yani, 2009, 9), and the trade liberalization through ASEAN PTA 1977, APEC Membership, and AFTA establishment in 1992. Therefore, the national interest and rational decision making were attributable in assessing the motive of Indonesia in its regionalism policy in Southeast Asia.

\section{Conclusion}

The beginning of the regional integration process in Southeast Asia is marked by the spread of the Cold War effect in the region. The role of Cold War in the regional integration process in Southeast Asia is visible in the occurrence of the ideological war between liberal democracy and communism in Southeast Asia. The growth of communist ideology and the expansionist policy of Soviet Union in Southeast Asia had evoked United States to implement the Containment Policy in Southeast Asia. Up to the end of 1966, three important regional institutions of Southeast Asia during the early period included SEATO, ASA and MAPHILINDO. ASEAN was established in 1967 by the ASEAN-5 States. However, the expansion of ASEAN membership took place from the year 1975 to 1999, with Brunei, Vietnam, Laos, Myanmar and Cambodia joining.

In conducting the regional integration process, "ASEAN Way" functions as the ground values for ASEAN. The values are comprised of the adherence to non-interference, sovereignty and non-use of force norms, the promotion of regional resilience value, and the preference for consultation and consensus mechanisms. Cooperation in political-security, socio-economic sectors and inter regional partnership construct what it is called as contemporary regionalism in Southeast Asia. The prominent fields of cooperation in political-security sector include the disarmament and non-proliferation of nuclear weapon, transnational crime and terrorism, South China Sea partnership, Human Rights protection, peaceful settlement of dispute, and extradition mechanism. Meanwhile, the prominent fields of cooperation in socio-economic sector include AFTA, AFAS, AICO, ACIA, freedom of movement, migrant worker protection, trans boundary 
haze pollution, women and children protection, and disaster management. ASEAN also expands its interregional cooperation scheme. ASEAN has established important partnership schemes of inter regional dialogue, free trade area, bilateral dialogue, sectoral dialogue partnerships and development partnership. ASEAN interregional partnerts include China, South Korea, Japan, Mongolia, North Korea, Turkey, Russia, Germany, Switzerland, Norway, Australia, Papua New Guinea, Timor Leste, New Zealand, India, Pakistan, Bangladesh, Sri Lanka, Canada and United States, European Union, and UNDP.

Southeast Asian Identity is constructed by the sovereignty, non-interference, informality through consensus and cooperation, national resilience, and regional resilience, ASEAN's selfacknowledgement as security cooperation, and the region's common sufferings during the Cold War Period as the main elements which construct regional identity. There are four important intergovernmentalism elements which construct the ASEAN regionalism process. They are 1) bargaining process through the informal mechanism, 2) process of integration in Southeast Asia significantly refers to bigger autonomy of member states based on sovereignty and consultation grounds, 3) inexistence of specific constitutional procedure, specific judicial procedure and the inexistence of unconsensual voting mechanism, and 4) the existence of bigger relative power in ASEAN regionalism process, which is Indonesia. Emphasis of Indonesia's foreign policy during the post independence period is the "Bebas-Aktif' Policy, or "Independence-Active" Policy. The "Bebas-Aktif' Policy embodies Indonesia's non-aligned nature in its foreign policy. Aside from the notable "Bebas-Aktif' Policy, Indonesia's foreign policy from time to time comprises similar regionalist approach, with focuses set on political-economic stability. Endorsement of the sovereignty and non-interference values to ASEAN by Indonesia reflects the contribution of Indonesia in the formation process of constitutive norms of ASEAN.

\section{BIBLIOGRAPHY}

Abdullah, T. (1989).Islam and Formation of Tradition in Indonesia, A Comparative Perspective, in J.C. Heesterman, et. al., India and Indonesia General Perspectives, Leiden, EJ Brill, p. $20-21$.

Acharya, A. Allan L. (2012). Collective Identity Formation in Asian Regionalism, ASEAN Identity and the Construction of the Asia-Pacific Regional Order. International Political Science Association Online Room.,[http,//paperroom.ipsa.org/papers/paper_7151.pdf], pp. 5-11.

Alber, E.(2017). ASEAN, The Association of Southeast Asian Nations, Council of Foreign Relations.

Antunes, S. Camisao I.(2017). Realism., in Stephen McGlinchey et. al.,International Relations Theory, Bristol, E-International Relations Publishing, 2017, p.15.

Artner,A. (2018). Role of Indonesia in the Evolution of ASEAN, The Journal of East Asian Affairs, Vol. 31.

Balassa, B. (1961).Towards a Theory of Economic Integration, Kyklos International Review For Social Sciences, Vol. 14 No. 1, pp.1-17.

Bell, D. DuignanB. (2017). Realism, Encyclopaedia Brittanica.

Bell, S. (2002). Institutionalism, Old and New, University of Queensland Institutional Digital Repository.

Börzel, T. (2016),Theorizing Regionalism, Cooperation, Integration, and Governance”, The Oxford Handbook of Comparative Regionalism, Oxford, Oxford University Press, pp. 43-44. 
Bulmer, S. (2015).Power Shift, Towards Germany Hegemony in the European Union?", Boğazıcı University-TUSIAD Foreign Policy Forum Research Report, pp. 14-18.

Cho, Y.C. (2009). Conventional and Critical Constructivist Approaches to National Security,An Analytical Survey, The Korean Journal of International Relations, Vol. 49 No. 3, pp. 78-81.

Cliff, R. (2015). China's Military Power, Cambridge, Cambridge University Press, , p. 244-246.

Coşkun, M. (2015). A Discussion on the Theories of European Integration, Does Liberal Intergovernmentalism Offer a Satisfactory Answer?",Suleyman Demirel UniversityThe Journal of Faculty of Economics and Administrative Sciences, Vol. 20 No. 2, p. 388.

Danielson, R. (2007). Nasser and Pan-Arabism Explaining Egypt's Rise in Power, Calhoun Inttitutional Archive of the Naval Postgraduate School.

Dellios, R.Ferguson,,R. J.(2017). The Politics and Philosophy of Chinese Power, The Timeless and The Timely, Lanham, Lexington Books, p. 104.

Eliassen, K. Arnadottir, A. (2014). Southeast Asian and European Integration Compared" in Mario Telo, European Union and New Regionalism, CompetingRegionalism and Global Governance in a Post-Hegemonic Era, Oxon, Routledge, p. 243.

Fawcett, L. (2012). The History and Concept of Regionalism", ESIL Conference Paper Series, Vol. 2 No. 1.

Fifield,R. H. (1979).National and Regional Interest in ASEAN, Competition and Cooperation in International Politics", Occasional Paper of Institute of Southeas Asian Studies, No. 57,p. 4.

Fry, G. W. (2008). Global Organizations, The Association of Southeast Asian Nations. New York, Chelsea House Publishers, , p. 43.

Gregorian, R. (2007).CLARET Operations and Confrontation 1964-1966",1991, in Ian Beckett, Modern Counter-Insurgency, London, Routledge, , p. 60.

Hamzah, B.A. (2014).ASEAN Relation with Dialogue Partner, 1989, in Iqrima Ulfiana, "Dialogue Partner in the ASEAN Development", Academia.edu, , p. 3.

Haryanto, A. (2014). Prinsip Bebas Aktif dalam Kebijakan Luar Negeri Indonesia,Perspektif Teori Peran" JIPSi, Jurnal Ilmu Politik dan Komunikasi, Vol.4 No. 2, p. 23.

Hatta, M.(1953). Indonesia's Foreign Policy”, Foreign Affairs, Vol. 31 No. 3,p. 444.

Hellendorff, B. Schmitz M. (2014). Indonesia, From Regional to Global Power?,GRIP Analysis, p. 3 .

Heng, D. (2009). Sino-Malay Trade and Diplomacy from the Tenth through the Fourteenth Century, Athens, OH, Ohio University Press, , p. 84.

Heng, P.K.(2014).The "ASEAN Way" and Regional Security Cooperation in South China Sea". EUI Working PapersRSCAS, No. 121.

Intal, Jr.,P.(2017).'The Road to ASEAN Economic Community', ASEAN@50, The ASEAN Journey, Reflections of ASEAN Leaders and Officials, Vol. 1, Jakarta, ERIA, p.269.

Japperson, R. et. al. (1996).Norms, Identity and Culture in National Security" in Peter Katzenstein, et. al.,The Culture of National Security, Columbia University Press, New York, pp. 52-53.

Jones, L. (2009).ASEAN and the Norm of Non-Intereference in Southeast Asia, A Quest of Social Order", Nuffield College Politics Group Working Paper. 
Jonsson, C. Tallberg J. (2001).Institutional Theory in International Relations", Lund University Research.

Katzenstein, P.(1996). The Culture of National Security, Norms and Identity in World Politics, New York, Columbia University Press, p. 5, 52-59.

Kim, H. J. Ping L.(2011).The Changing Role of Dialogue in International Relations of Southeast Asia", Asian Survey, Vol. 51 No. 5, [doi,10.1525/as. 2011.51.5.953], p.953957.

Koh, T. (2017). ASEAN and EU, the Difference and Challenges, Strait Times, August.

Layne, C. (2018).The US-Chinese Power Shift and the End of Pax Americana”, International Affairs, Vol.94.

Leffler, M. (2006). Remembering George Kennan, Lessons for Today', Washington, DC,United States Institute of Peace, , p. 2

Leifer, M.(1973).Continuity and Change in Indonesian Foreign Policy”, Asian Affairs, Vol. 4 No. 2, , p. 173.

Liew, V.K. et al. (2017).The Impact of ASEAN Free Trade Area on Intra-ASEAN Manufacturing Trade", International Journal of Business and Society, Vol. 18 No. 3, p. 641.

Mansor, S.Radam, A. (2000). ASEAN Industrial Cooperation and Intra-ASEAN Trade, The Malaysian Case", in Muzafar Shah Habibullah, 'ASEAN in an IndependentWorld, Studies on Trade an Finance', Oxon, Routledge (Revivals).

Manurung, H. (2018)“Indonesia Menuju Poros Maritim Dunia” ("Indonesia Towards Global Maritime Axis"), Seminar Nasional Pakar ke-1 2018, Vol. 2, p. 148.

Masala, C. Roloff. R.(2000). Herausforderungen der Realpolitik (Challenges of Realpolitik), Köln, SYH-Verlag, 1998, pp. 61-94 in Heiner Hanggi, "Interregionalism,Empirical and Theoretical Perspective", The Center for Applied Policy Research,

Merced, L.D. (2017). Partners' for Change, Understanding the External Relations of ASEAN", Republic of The Philippines Foreign Service Institute.

Moravcsik, A. (2008). Negotiating the Single European Act, national interests andconventional statecraft in the European Community, in Hidetaka Yoshimatsu, The Political Economy of Regionalism in East Asia, Integrative Explanation for Dynamics and Challenges, Basingstoke, Palgrave Macmillan, p. 63.

Narine, S. (2002). Explaining ASEAN, Regionalism in Southeast Asia. Boulder, Lynne Rienner Publishers,

Neumann, I. (1992). Regional Great Powers in International Politics, Basingstoke, St. Martin's Press, p. 12.

Ness, G. D. (2015). ASA- The First Asian International [Letter written May 1, 1962 to Richard Nolte, Institute of Current World Affairs.]", Institute of Current World Affairs, pp. 1-4.

Ngan, T. (2016).Neo-realism and the Balance of Power in Asia", The International Studies Association.

Normala, A.(2018). A Peek at Southeast Asia's Strongest Military, Jakarta Globe.

Olsen, J. P. (2007). Understanding Institutions and Logics of Appropriateness, Working Paper No. 13, Retrieved from ARENA Centre for European Studies University of Oslo.

Peter, G. (1999). Institutional Theory in Political Science, The 'New Institutionalism, London, Continuum, 
Pilliter, R. J. (1969).The Evolution of the US Containment Policy in Asia", University of Windsor Master Thesis, pp. 85-86.

Puj1astut1, S. et. al.(2007). IPS Terpadu 3B (Integrated Social Sciences 3B), Jakarta, Esis Erlangga, pp. 86-87.

Putera, E. W.(2018).Esensi Hubungan Internasional dan Kebijakan Politik LuarNegeri Indonesia", Secretariat of the Cabinet of the Republic of Indonesia, September.

Rattanasevee,P. (2014). Towards Institutionalised Regionalism, the Role of Institutions and Prospects for Institutionalisation in ASEAN", SpringerPlus, Vol.3 No.556.

Ravenhill, J. (2001). APEC and the Construction of Pacific Rim Regionalism, Cambridge, Cambridge University Press, pp. 105-107.

Rawi,A., et. al. (2006).Identity as a Variable, Perspectives on Politics. Vol. 4, p. 711 in Amitav Acharya and Allan Layug, "Collective Identity Formation in Asian Regionalism, ASEAN Identity and the Construction of the Asia-Pacific Regional Order". International Political Science Association Online Paper Room. 2012, [http,//paperroom.ipsa.org/papers/paper_7151.pdf], pp. 5-11.

Reid, Anthony. (2010). Imperial Alchemy, Nationalism and Political Identity in Southeast Asia. Cambridge, Cambridge University Press, p. 100.

Rosamond, B. (2000). Theories of European Integration. Basingstoke, Palgrave Macmillan, p. 60.

Schimmelfenning,F. Rittberger, B. (2006), Theories of European Integration, Assumptions and Hypotheses, in Jeremy Richardson, European Union, Power andPolicy Making, Oxon, Routledge, pp. 77-78.

Schonard, M. (2018),Supranational Decision-Making Procedures", European Parliament.

Shekhar, V.(2018). Indonesia's Foreign Policy and Grand Strategy in the $21^{\text {st }}$ Century, Rise of an Indo-Pacific Power, Oxon, Routledge, pp. 15-17.

Situmorang, M. (2017). Indonesia, Maintaining a Leading Role in Making of ASEANand APT Community", 2017, in Lai To Lee \& Zarina Othman, Regional CommunityBuilding in Southeast Asia, Countries in Focus, Oxon, Routledge, p. 64.

Stein, A. (2008). Neoliberal Institutio", 2008 in Christian Reus-Smit \& Duncan Snidal, TheOxford Handbook on International Relations, New York, Oxford University Press, pp. 208-209.

Stockwell, A.J. (2004). British Documents on the End of the Empire, Malaysia. London, TheStationery Office,

Sweet, A.S.,Sandholtz, W. (1997). European Intergration and SupranationalGovernance", Journal of European Public Policy, Vol. 4 No. 3, p. 301.

Toru, Y. (2004). Regional Integration in the Americas and North-South Relations", TheJapan Institute of International Affairs, http,//www2.jiia.or.jp/pdf/asia centre/h15 japan/3.yanagihara.pdf pp.3-4.

Tripathi, D. (2015). Beyond Pessimism, Analysing Prospect for Asian RegionalismWith Cooperation Between India, China and ASEAN', Ylldiz Social Science Review, Vol. 1No. 2, pp. 69-70.

Tulun, T. (2018). ASEAN's Deficiency In Dealing With Security Arena”, AVIM,November Ulfiana, I. (2014). Dialogue Partner in the ASEAN Development", Academia.edu, pp. 2-3. 
Vatikiotis, MRJ.( "ASEAN 10, The Political and Cultural Dimensions ofSoutheast Asian Unity”, Southeast Asian Journal of Social Science, Vol. 27 No. 1,1999, p. 77.

Vejjajiva,A. (2017). The Critical Importance of Social-cultural Community for the Futureof ASEAN", ASEAN@50, Building ASEAN Community, Political-Security and SocioCultural Reflections Vol. 4, Jakarta, ERIA, , p. 352.

Weber, K. (2009). ASEAN, A Prime Example of Regionalism in Southeast Asia", EuropeanUnion Miami Analysis Special Series, Vol. 6 No. 5, p. 4.

Wendt, A. (1994).Collective Identity Formation and the International State", TheAmerican Political Science Review, Vol. 88, No. 2, p. 385.

Williams,P. Goldstein, D. Shafritz, J.M. (2006). Classic Readings andContemporary Debates in International Relations', in Jia Chen, "Factorsshaping regional integration in Europe, Asia, and Africa, the validity ofcompetingtheories", Lethbridge University Master Thesis, 2011, pp. 27.

Wolters, O.W.(1999).History, Culture, and Region in Southeast Asian Perspective, Ithaca,Southeast AsiaProgram Publications Cornell University, pp. 27-33.

Yang, C. (2009). Analysis on the Service Trade Between China and ASEAN,International Journal of Economics and Finance, Vol. 1 No. 1, pp. 221-224.

Yani, Y. (2009).Change and Continuity in Indonesian Foreign Policy", Sosiohumaniora,Vol.11 No. 1, pp. 8.

Yoshimatsu, H. (2008). The Political Economy of Regionalism in East Asia, IntegrativeExplanation for Dynamics and Challenges, New York, Palgrave Macmillan, p.7. 